\title{
HLA typing in families with multiple cases of rheumatoid arthritis
}

\author{
M Strotzer, H Menninger, S Scholz, E D Albert
}

\begin{abstract}
Thirty one white patients from 14 families with multiple cases of rheumatoid arthritis (RA) and 42 of their healthy relatives were completely HLA typed. In contrast with class I antigens, the class II antigens DR1 and DR4 were significantly more common in the patients than in a group of $\mathbf{2 0 0}$ healthy local white controls (DR1: $32 \%$ v 12\%; DR4: 48\% v 28\%, in patients and controls respectively).

Owing to the small number of cases the data from this study were combined with those of published reports. Examination of patients for DR1 and DR4 homozygosity and DR1/4 heterozygosity showed an increase of DR1 homozygous patients, which was not statistically significant. There was no striking deviation from random expectation in haplotype sharing of affected sib pairs. These results are compatible with a dominant influence of DR1 and DR4 in the mode of inheritance. The nearly random haplotype sharing and the molecular relation between DR1 and DR4 support the hypothesis of a direct influence of these antigens in the pathogenesis of RA.

Only $68 \%$ of the patients in this study possessed either DR1 or DR4, possibly indicating a subtype of $R A$ which is independent of HLA.
\end{abstract}

Table 1 Tissue typing of patients with rheumatoid arthritis

\begin{tabular}{|c|c|c|c|c|c|c|c|c|c|}
\hline \multirow{2}{*}{$\begin{array}{l}\text { Family } \\
\text { No }\end{array}$} & \multirow[t]{2}{*}{ Transmission } & \multicolumn{4}{|c|}{ Haplotype A, HLA- } & \multicolumn{4}{|c|}{ Haplotype $B, H L A-$} \\
\hline & & $\boldsymbol{A}$ & $\boldsymbol{B}$ & $C w$ & $D R$ & $A$ & $B$ & $C w$ & $D R$ \\
\hline 1 & $\begin{array}{r}{ }^{*} \text { Sister } \\
\text { Sister }\end{array}$ & $\begin{array}{l}3 \\
3\end{array}$ & $\begin{array}{l}\text { w56 } \\
\text { w56 }\end{array}$ & $\begin{array}{l}1 \\
1\end{array}$ & $\begin{array}{l}4 \\
4\end{array}$ & $\begin{array}{l}2 \\
1\end{array}$ & $\begin{array}{l}44 \\
51\end{array}$ & $\begin{array}{l}1 \\
1\end{array}$ & $\begin{array}{l}7 \\
4\end{array}$ \\
\hline 2 & $\begin{array}{c}{ }^{*} \text { Sister } \\
\text { Sister } \\
\text { Sister }\end{array}$ & $\begin{array}{l}3 \\
3 \\
3\end{array}$ & $\begin{array}{l}7 \\
7 \\
7\end{array}$ & $\frac{-}{7}$ & $\begin{array}{l}1 \\
1 \\
4\end{array}$ & $\begin{array}{l}3 \\
3 \\
3\end{array}$ & $\begin{array}{l}35 \\
35 \\
35\end{array}$ & $\begin{array}{l}4 \\
4 \\
4\end{array}$ & $\begin{array}{l}4 \\
4 \\
7\end{array}$ \\
\hline 3 & *Sister & 30 & 13 & 6 & 7 & 3 & 62 & 3 & 4 \\
\hline & $\begin{array}{l}\text { Sister } \\
\text { Cousin }\end{array}$ & $\begin{array}{l}1 \\
24\end{array}$ & $\begin{array}{l}8 \\
18\end{array}$ & $\begin{array}{l}7 \\
7\end{array}$ & $\begin{array}{l}3 \\
1\end{array}$ & $\begin{array}{l}2 \\
2\end{array}$ & $\begin{array}{l}8 \\
27\end{array}$ & $\begin{array}{l}7 \\
2\end{array}$ & $\begin{array}{l}\text { w6 } \\
1\end{array}$ \\
\hline 4 & $\begin{array}{l}{ }^{*} \text { Brother } \\
\text { Sister }\end{array}$ & $\begin{array}{l}24 \\
24\end{array}$ & $\begin{array}{l}27 \\
27\end{array}$ & $\begin{array}{l}2 \\
2\end{array}$ & $\begin{array}{l}1 \\
5 \\
5\end{array}$ & $\begin{array}{l}3 \\
29\end{array}$ & $\begin{array}{l}35 \\
44\end{array}$ & 4 & $\begin{array}{l}1 \\
7\end{array}$ \\
\hline 5 & $\begin{array}{c}{ }^{*} \text { Sister } \\
\text { Sister } \\
\text { Sister }\end{array}$ & $\begin{array}{l}3,26 \\
26 \\
26\end{array}$ & $\begin{array}{l}13, w 55 \\
44 \\
44\end{array}$ & $\begin{array}{l}3,6 \\
7 \\
7\end{array}$ & $\begin{array}{l}1,7 \\
\text { w6 } \\
\text { w6 }\end{array}$ & $\begin{array}{l}2 \\
2\end{array}$ & $\begin{array}{l}44 \\
44\end{array}$ & $\begin{array}{l}5 \\
5\end{array}$ & $\begin{array}{l}\text { w8 } \\
\text { w8 }\end{array}$ \\
\hline 6 & $\begin{array}{l}{ }^{*} \text { Sister } \\
\text { Sister }\end{array}$ & $\begin{array}{l}1,26 \\
10,31\end{array}$ & $\begin{array}{l}8, w 62 \\
14, w 41\end{array}$ & $\begin{array}{l}3,7 \\
8\end{array}$ & $\begin{array}{l}4,3 \\
5, w 6\end{array}$ & & & & \\
\hline 7 & $\begin{array}{l}{ }^{*} \text { Sister } \\
\text { Sister }\end{array}$ & $\begin{array}{l}3,29 \\
26,28\end{array}$ & $\begin{array}{l}7,44 \\
39,44\end{array}$ & $\begin{array}{l}7 \\
5\end{array}$ & $\begin{array}{l}4, w 6 \\
2,5\end{array}$ & & & & \\
\hline 8 & $\begin{array}{r}{ }^{*} \text { Sister } \\
\text { Sister }\end{array}$ & $\begin{array}{l}2,3 \\
2,11\end{array}$ & $\begin{array}{l}18,35 \\
5\end{array}$ & 4 & $\begin{array}{l}4 \\
2\end{array}$ & & & & \\
\hline 9 & $\begin{array}{l}\text { Mother } \\
{ }^{*} \text { Daughter }\end{array}$ & $\begin{array}{l}25 \\
25\end{array}$ & $\begin{array}{l}\text { w52 } \\
\text { w52 }\end{array}$ & - & $\begin{array}{l}5 \\
5\end{array}$ & $\begin{array}{l}3 \\
23\end{array}$ & $\begin{array}{l}38 \\
7\end{array}$ & - & w6 \\
\hline 10 & $\begin{array}{l}\text { * Mother } \\
\text { Son }\end{array}$ & $\begin{array}{l}3 \\
3\end{array}$ & $\begin{array}{l}8 \\
8\end{array}$ & $\overline{-}$ & $\begin{array}{l}1 \\
1\end{array}$ & $\begin{array}{l}2 \\
1\end{array}$ & $\begin{array}{l}8 \\
35\end{array}$ & - & $\begin{array}{l}3 \\
2\end{array}$ \\
\hline 11 & $\begin{array}{l}{ }^{*} \text { Mother } \\
\text { Daughter }\end{array}$ & $\begin{array}{l}2 \\
2\end{array}$ & $\begin{array}{l}\text { w60 } \\
\text { w60 }\end{array}$ & $\begin{array}{l}3 \\
3\end{array}$ & $\begin{array}{l}4 \\
4\end{array}$ & $\begin{array}{l}28 \\
2\end{array}$ & $\begin{array}{l}49 \\
w 60\end{array}$ & $\begin{array}{l}7 \\
3\end{array}$ & 5 \\
\hline 12 & $\begin{array}{l}\text { * Mother } \\
\text { Daughter }\end{array}$ & $\begin{array}{l}2 \\
2\end{array}$ & $\begin{array}{l}44 \\
44\end{array}$ & $\begin{array}{l}5 \\
5\end{array}$ & $\begin{array}{l}4 \\
4\end{array}$ & $\begin{array}{l}30 \\
2\end{array}$ & $\begin{array}{l}39 \\
8\end{array}$ & $\frac{-}{7}$ & $\begin{array}{l}5 \\
4\end{array}$ \\
\hline 13 & $\begin{array}{l}\text { *Father } \\
\text { Daughter }\end{array}$ & $\begin{array}{l}2,23 \\
2,23\end{array}$ & $\begin{array}{l}27,44 \\
27,44\end{array}$ & $\begin{array}{l}1,4 \\
2,4\end{array}$ & $\begin{array}{l}2,7 \\
2,7\end{array}$ & & & & \\
\hline 14 & $\begin{array}{l}{ }^{*} \text { Mother } \\
\text { Daughter }\end{array}$ & $\begin{array}{l}3 \\
3\end{array}$ & $\begin{array}{l}8 \\
8\end{array}$ & 7 & 1 & $\begin{array}{l}31 \\
11\end{array}$ & $\begin{array}{l}\text { w55 } \\
18\end{array}$ & $\begin{array}{l}1 \\
2\end{array}$ & $\begin{array}{l}4 \\
4\end{array}$ \\
\hline
\end{tabular}

*Index case
Clinical and serological variables were measured and indicated no significant difference between DR1 (or DR4) positive and DR1 (or DR4) negative disease. In this small group of patients the clinical course of RA seemed to be determined mainly by other genetic or environmental factors.

HLA studies of families with multiple cases of rheumatoid arthritis (RA) have shown a statistical association between the disease and HLADR4, but we know that in some ethnic groups this association does not occur. Some of these populations show a significant increase in the prevalence of DR1 in patients with RA..$^{1-3}$ The question whether DR antigens themselves or linked genes predispose to RA has not yet been answered. Analysis of haplotype sharing and calculation of lod scores provided inconclusive results. ${ }^{45}$

\section{Patients and methods}

PATIENTS

We typed 31 white patients with definite or classical RA (American Rheumatism Association criteria) and 42 of their healthy relatives. In each of the 14 families we found at least two first degree relatives with the disease. In six families one parent and one daughter or son were affected and in eight families the patients were siblings.

\section{TISSUE TYPING}

Tissue typing for HLA-A, B, C, ${ }^{6}$ and $\mathrm{DR}^{7}$ antigens was performed by the microdroplet lymphocyte cytotoxicity test described by Terasaki and McClelland. The results are shown in table 1 .

\section{CLINICAL AND SEROLOGICAL INVESTIGATIONS}

The degree of articular disease was estimated by the spread-severity index published by Walker. ${ }^{8}$ Comparable $x$ ray grading was reached by the standard radiographs of Larsen 9 and the calculation index described by Walker. ${ }^{8}$ Rheumatoid factor titre was measured by nephelometry. Antinuclear antibodies were investigated by indirect immunofluorescence.

\section{STATISTICAL ANALYSIS}

Calculation of statistical significance was by the $\chi^{2}$ test with Yates's correction. For testing in table 2 we used only the index case of each 
family. In table 3 only the index case was compared with his affected siblings. This is important to avoid overrepresentation of families with more than two patients.

\section{Results}

None of the class I antigens (HLA-A, B, and C) was more prevalent in patients than in healthy controls.

\section{DR PREVALENCES (table 2)}

In our group both antigens DR1 and DR4 show a significant association with RA (DRl: $32 \% v$ $12 \%, \mathrm{p}<0.005$; DR4: $48 \%$ v $28 \%$, $\mathrm{p}<0.01$ for patients and controls respectively). This reflects the results of other investigators.

\section{NUMBER OF HOMOZYGOTES}

We analysed our data and those of other reported family studies and found $\mathbf{1 1 0}$ families with 213 patients who had been completely HLA typed. ${ }^{10-22}$ The gene prevalence was $13.6 \%$ for DR1 and $49.5 \%$ for DR4. The Hardy-Weinberg-formula suggests that four DR1 and 52 DR4 homozygous patients might

Table 2 Prevalence of HLA-DR antigens (31 patients, 200 healthy controls)

\begin{tabular}{lcc}
\hline Antigen & $\begin{array}{c}\text { Patients } \\
\text { No (\%) }\end{array}$ & $\begin{array}{l}\text { Healthy } \\
\text { controls } \\
\text { No (\%) }\end{array}$ \\
\hline DR1 & $10(32)$ & $24(12)^{*}$ \\
DR2 & $6(19)$ & $56(28)$ \\
DR3 & $3(10)$ & $41(21)$ \\
DR4 & $15(48)$ & $56(28) \dagger$ \\
DR5 & $8(26)$ & $75(38)$ \\
DRw6 & $6(19)$ & $46(23)$ \\
DR7 & $7(23)$ & $41(21)$ \\
DRw8 & $2(6)$ & $20(10)$ \\
DRw9 & $0(0)$ & $3(2)$ \\
DRw10 & $0(0)$ & $4(2)$ \\
\hline$\chi^{2}=7 \cdot 93, p<0 \cdot 005$. & & \\
$t \chi^{2}=6 \cdot 52$, p $<0.01$. & \\
For $\chi^{2}$ testing only index cases were used.
\end{tabular}

Table 3 Haplotype sharing in affected sib pairs (referring to 15 multiple case family studies, $5810-182324$ ) including 181 families plus our own data

\begin{tabular}{|c|c|c|c|c|}
\hline \multirow[t]{2}{*}{ Reference } & \multirow{2}{*}{$\begin{array}{l}\text { Number of } \\
\text { families }\end{array}$} & \multicolumn{3}{|c|}{ Shared haplotypes: } \\
\hline & & 0 & 1 & 2 \\
\hline 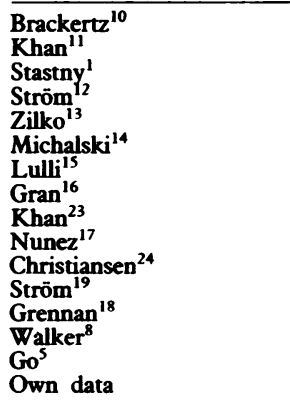 & $\begin{array}{r}2 \\
5 \\
21 \\
5 \\
7 \\
1 \\
2 \\
6 \\
51 \\
6 \\
16 \\
2 \\
35 \\
13 \\
9 \\
8\end{array}$ & $\begin{array}{l}0 \\
0 \\
3 \\
1 \\
2 \\
1 \\
1 \\
1 \\
7 \\
2 \\
5 \\
1 \\
5 \\
3 \\
1 \\
7\end{array}$ & $\begin{array}{r}2 \\
4 \\
11 \\
4 \\
7 \\
0 \\
0 \\
3 \\
25 \\
5 \\
11 \\
1 \\
20 \\
6 \\
7 \\
2\end{array}$ & $\begin{array}{r}0 \\
1 \\
7 \\
3 \\
1 \\
1 \\
1 \\
2 \\
19 \\
3 \\
4 \\
0 \\
17 \\
5 \\
2 \\
1\end{array}$ \\
\hline $\begin{array}{l}\text { Total number } \\
\% \text { Found } \\
\text { Random expectation (\%) } \\
\chi^{2}=3 \cdot 3 ; \text { NS }\end{array}$ & 189 & $\begin{array}{l}40 \\
18 \cdot 6 \\
25\end{array}$ & $\begin{array}{l}108 \\
50 \cdot 2 \\
50\end{array}$ & $\begin{array}{l}67 \\
31 \cdot 2 \\
25\end{array}$ \\
\hline
\end{tabular}

In families with more than two patients only the index case was compared with his affected siblings. be expected, whereas $10 \mathrm{DR} 1$ homozygous and 51 DR4 homozygous cases were found. The increased number of DR1 homozygotes was not statistically significant. These figures indicate the dominant influence of DR1 and DR4 in the inheritance of RA.

\section{HAPLOTYPE SHARING}

Table 3 does not show any striking deviation from random expectation in haplotype sharing of affected siblings. The results of some studies (especially small ones) are widely differing and our own figures are surprising, but almost certainly caused by the small number of sib pairs.

Two important studies ${ }^{25} 26$ with 26 multicase families each showed increased haplotype sharing but these are not listed in table 3 because the data have been published in a form that does not allow statistical comparison.

The data do not prove the hypothesis of an $R A$ gene in linkage disequilibrium with $D R 1$ and DR4, but suggest that certain HLA-DR antigens play a direct part in the pathogenetic process.

CLINICAL AND SEROLOGICAL INVESTIGATIONS

No significant association was found between patients with DRl or DR4 positive RA and the following variables: rheumatoid factor titre, antinuclear factor titre, age at onset of the disease, $x$ ray index (Larsen/Walker ${ }^{8}$ ), and spread-severity index. ${ }^{8}$ The discrepancy in the clinical course and serological findings between siblings with RA was surprising, even in HLA identical sib pairs. It seems that the severity of the disease was mainly determined by factors other than the HLA antigens, though published reports have shown that the prevalence of DR4 is slightly greater in seropositive patients than in seronegative RA. ${ }^{115} 16$ 27-31

\section{Discussion}

The association of RA and the HLA antigens DR1 and DR4 is well established, but it is not clear how these antigens affect the development of RA. If a hypothetic susceptibility gene for RA was linked to the major histocompatibility complex this should result in an increased haplotype sharing of affected siblings. Table 3 shows that this cannot be confirmed. Bodmer ${ }^{32}$ tried to explain this observation as follows $(a)$ the HLA linked disease gene is effectively dominant and has a relatively high frequency and therefore a low penetrance; $(b)$ the disease consists of a mixture of two forms, one of which is HLA linked and the other which is not. Bodmer proved that in each of these situations a distortion in the haplotype sharing of affected siblings might be difficult to detect.

Investigations with monoclonal antibodies (MoAb 109d6) reported by Lee ${ }^{33}$ showed cross reactions between DR1 and DR4 positive lymphocytes. A DNA sequence analysis found the identity of the third hypervariable region of class II $\beta$ chains in DRI and in the Dw14 subtype of DR4. ${ }^{34}$ This supports the common 
immunological background of DR1 and DR4 positive RA. This 'shared epitope hypothesis' is an alternative to the idea of an HLA linked RA susceptibility gene.

In our patients only $68 \%$ express either DRl or DR4 (table 1). This fact leads to the assumption of a subtype of RA which is independent of HLA and supports Bodmer's second hypothesis. It will be interesting to see whether further research verifies the existence of RA independent of the major histocompatibility complex and thus shows the genetic heterogeneity of the RA syndrome.

1 Stastny P. Rheumatoid arthritis. In: Terasaki P I, ed. Histocompatibility testing 1980: Los Angeles: UCLA, 1980: 681-6.

2 SchiffB, Mizrachi Y, Orgad S, Yaron M, Gazit E. Association of HLA-Aw31 and HLA-DRI with adult rheumatoid arthritis. Ann Rheum Dis 1982; 41: 403-4.

3 Woodrow J C. Rheumatoid arthritis in British and Asian oodrow $J$ C. Rheumatoid arthritis in British and Asian Indian populations. In: Dawkins $R \mathbf{L}$, Christiansen F T, Zilko P J, eds. Immunogenetics in rheumatology. Am

4 Walker D J, Burn J, Griffiths I D, Roberts D F, Stephenson A M. Linkage studies of HLA and rheumatoid arthritis in multicase families. Arthritis Rheum 1987; 30: 31-5.

5 Go R C P, Alarcon G S, Acton R T, Koopman W J, Vittor V J, Barger B O. Analysis of HLA linkage in white families with multiple cases of seropositive rheumatoid arthritis. Arthritis Rheum 1987; 30: 115-21.

6 Terasaki P I, McCurdy B, McClelland J. Microdroplet lymphocyte cytotoxicity test. In: Ray J G, Scott R C, Hare D B, Harris C E, Kayhoe D E, eds. Manual of tissue typing D B, Harris C E, Kayhoe D E, eds. Manual of tissue typing techniques. Washington DC: DHEW Pub

7 van Rood J J, van Leeuven A, Keuning J J, van Oud Alblas A B. The serological recognition of the human MLC determinants using a modified cytotoxicity technique. Tissue Antigens 1975; 5: 73-9.

8 Walker D J, Griffiths M, Dewar P, et al. Association of MHC antigens with susceptibility to and severity of rheumatoid arthritis in multicase families. Ann Rhewm Dis 1985; 44: 519-25.

9 Larsen A, Dale K, Eek M. Radiographic evaluation of rheumatoid arthritis and related conditions by standard reference films. Acta Radiol [Diagn] (Stockh) 1977; 18: 481-91.

10 Brackertz D. Chromische Polyarthritis. Basle: EULAR, 1979: 171-85.

11 Khan M A, Kushner I, Braun W E, Dejelo C L, Ballou S P. Clinical and HLA studies in multiple case families with rheumatoid arthritis. Tissue Antigens 1981; 18: 136-8.

12 Ström H, Möller E. HLA and rheumatoid arthritis. A study of five families. Tissue Antigens 1981; 18: 92-100.

13 Zilko P J, Dawkins R L. Rheumatoid arthritis. In: Dawkins R L, Christiansen F T, Zilko P J, eds. Immunogenetics in rhevematology. Amsterdam-Oxford-Princeton: Excerpta Medica, 1982: 143-7.

14 Michalski J P, McCombs C C, DeJesus I B, Anderson J L. HLA haplotypes in a family with multiple cases of heumatoid arthritis. $\mathcal{F}$ Rhewmatol 1982; 9: 451-4.

15 Lulli P, Cappellaci S, Morellini M, Galeazzi M, Schiavetti L, Tuzi T. HLA antigens and rheumatoid arthritis. Arthritis Rhewn 1983; 26: 1053-4.

16 Gran J T, Husby G, Bratlie A, Thorsby E. HLA haplotypes in multiple case families with rheumatoid arthritis. Clin Rherematol 1984; 3: 173-80.

17 Nunez G, Moore S E, Ball G V, Hurd E R, Stastny P. Study of HLA antigens in ten multiple case rheumatoid arthritis families. I Rhewonatol 1984; 11: 129-35.

18 Grennan D M, Dyer P, Dodds W, et al. Clinical and immunogenetic studies in multicase rheumatoid families. $Q$ immunogenetic studies in $1984 ; 212: 479-85$.

19 Ström H, Dahlqvist S R, Bjello A, Möller E. HLA genotypes in two three-generation families with rheumatoid arthritis. Hum Immunol 1985; 13: 243-51.

20 Hazelton R A, Dick H M, McCay S, Sturrock R D. Immunogenetic insights into rheumatoid arthritis: a family study. Qf Med 1982; 203: 336-40.

21 Rossen $\mathbf{R}$ D, Brewer E J, Sharp R M, et al. Familial rheumatoid arthritis: a kindred identified through a proband with seronegative juvenile arthritis includes members with seropositive, adult-onset disease. Hum Immunol 1982; 4: 183-96.

22 Read C, Grennan D M, Dyer P, et al. HLA and blood group markers in multicase rheumatoid families-sibship and markers in multicase rheumatoid families-

23 Khan M A. HLA haplotypes in multiple case families with rheumatoid arthritis. Clin Rhewmatol 1984; 3: 557-8.

24 Christiansen F T, Kelly H, Dawkins R L. Rheumatoid arthritis. In: Albert E D, Baur M P, Mayr $W R$, eds. Histocompatibility testing 1984. Berlin-Heidelberg-New York-Tokyo: Springer, 1984: 378-83.

25 McDermott M, Molloy M, Cashin P, et al. A multicase family study of rheumatoid arthritis in south west Ireland. Dis Markers 1986; 4: 103-11.

26 Ollier W, Silman A, Gosnell N, et al. HLA and rheumatoid arthritis: An analysis of multicase families. Dis Markers 1986 ; 4: 85-98.

27 Dobloug J H, Foerre O, Kass E, Thorsby E. HLA antigens and rheumatoid arthritis. Arthritis Rhewe 1980; 23: 309-13.

28 Jaraquemada D, Ollier W, Awad J, et al. HLA and rheumatoid arthritis: a combined analysis of 440 British patients. Ann Rhewm Dis 1986; 45: 627-36.

29 Bardin T, Legrand L, Naveau B, et al. HLA antigens and seronegative rheumatoid arthritis. Ann Rheum Dis 1985; 44: 50-3.

30 Brautbar C, Naparstek Y, Yaron M, et al. Immunogenetics of rheumatoid arthritis in Israel. Tissue Antigens 1986; 28: 8-14.

31 Swiss collaborative study. HLA-DR antigens in rheumatoid arthritis. Rherematol Int 1986; 6: 89-92.

32 Bodmer W F. The HLA system, 1984. In: Albert E D, Baur $M$ P, Mayr W $R$, eds. Histocompatibiling testing 1984. Berlin-Heidelberg-New York-Tokyo: Springer: 1984: 11-22.

33 Lee S H, Gregersen P K, Shen H H, Winchester R J. Genetic susceptibility in rheumatoid arthritis is associated with non DR Ia allodeterminants [Abstract]. Arthritis Rheum 1980; 23: S36.

34 Gregersen P K, Silver J, Winchester R J. The shared epitope hypothesis. Arthritis Rhewn 1987; 30: 1205-13. 